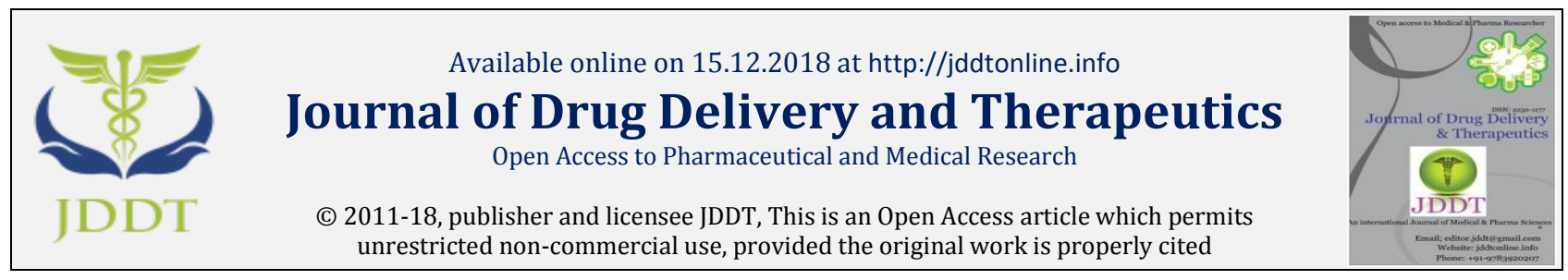

Open $\odot$ Access

Review Article

\title{
Ethnobotanical uses and pharmacological activities of Argyreia cuneata (Willd.) Ker Gawl. (Convolvulaceae) - A review.
}

\author{
Prashith Kekuda T.R. ${ }^{*}$, Vinayaka K.S. ${ }^{2}$ \\ 1Department of Microbiology, S.R.N.M.N College of Applied Sciences, N.E.S campus, Balraj Urs Road, Shivamogga-577201, Karnataka, India \\ 2Department of Botany, Kumadvathi First Grade College, Shimoga Road, Shikaripura-577427, Karnataka, India
}

\begin{abstract}
Argyreia cuneata (Willd.) Ker Gawl. is a sub-erect silky shrub and belongs to the family Convolvulaceae. An updated information on ethnobotanical uses and pharmacological activities of $A$. cuneata is presented in this review. The plant finds traditional uses as a remedy for human and veterinary ailments. The plant is used to treat diabetes, helminthic infections, skin cuts, to initiate labor pain and to ease delivery. As an ethnoveterinary practice, the plant is used against retention of fetal membrane, anorexia and swelling of throat. The plant is reported to contain phytochemicals such as alkaloids and flavonoids. The plant is shown to exhibit some pharmacological activities viz. analgesic, antibacterial, antifungal, antioxidant, wound healing, antipyretic, anthelmintic and antidiabetic activities.
\end{abstract}

Keywords: Argyreia cuneata (Willd.) Ker Gawl., Ethnobotanical, Traditional uses, Phytochemistry, Pharmacological activities

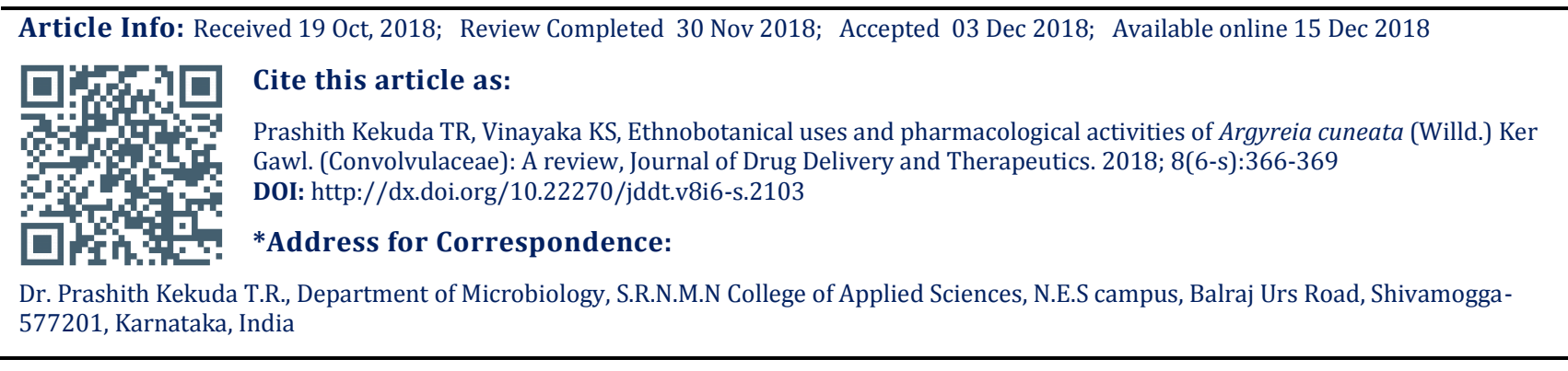

\section{INTRODUCTION}

Ethnobotany is the study of interaction between humans and surrounding flora. Since ancient time, plants are helpful to mankind as an important sources of food, medicine, construction tools, spices and dyes. Indigenous practitioners and traditional medicinal systems of various parts of the world utilize various parts of plants in certain formulations for healthcare benefits. Many plant secondary metabolites are being used as therapeutic agents in modern medicinal systems ${ }^{\mathbf{1 - 9}}$. The plant genus Argyreia Lour. belongs to the family Convolvulaceae and represents over 125 species distributed worldwide. The genus is taxonomically complex and difficult of the Asian genera of Convolvulaceae. The members of the genus are medicinally important and are large twining or prostrate shrubs that are rarely erect. Leaves are usually silky or pubescent beneath. Flowers are large, in axillary cymes and usually purple, red or rose colored with funnel shaped corolla. Ovary is 2-4 celled. Fruit is a leathery, dry or fleshy indehiscent berry with 4 or less seeds $\mathbf{1 0 , 1 1 , 1 2}$.
Argyreia cuneata (Willd.) Ker Gawl. (Figure 1) belonging to the family Convolvulaceae is a suberect silky shrub with showy red flowers. The plant is popularly known by the name Purple morning glory and purple convolvulus in English and Achee gida, Aachari gida, Kallana hambu in Kannada. The plant is found distributed in South India and common across the plains along the hedges. In Karnataka, the plant is found distributed in various localities such as Bangalore, Shivamogga, Chitradurga, Chikmagalur, Hassan, Davanagere, Kodagu and Uttara Kannada ${ }^{\mathbf{1 3}-18}$. The plant is often cultivated in garden due to its showy flowers that draw attention and the leaves are reported to be effective in diabetes ${ }^{19}$. The plant is shown to be one of the host plants for tortoise beetles ${ }^{20}$. The study by Pimpodkar et al. ${ }^{21}$ revealed the potential application of flower extract of A. cuneata as natural indicator in acid base titration. In this review, details on various aspects viz. phytochemistry, ethnomedicinal uses and pharmacological activities of Argyreia cuneata (Willd.) Ker Gawl., obtained by referring standard flora, journals and search engines (ScienceDirect, PubMed, Google Scholar), is presented. 


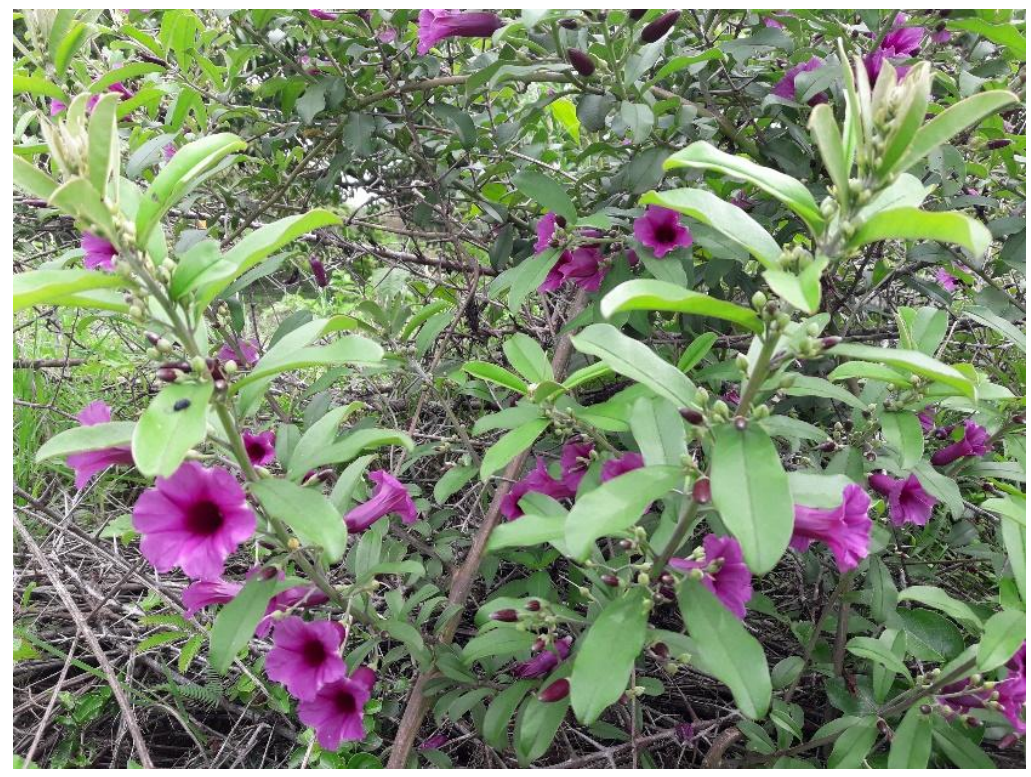

Figure 1: Argyreia cuneata

\section{PLANT DESCRIPTION}

A. cuneata is a suberect shrub with a climbing tendency and grows to a height of $1.5 \mathrm{~m}$. The leaves are obovatelanceolate, 4-7 x 2-4 cm, emarginate, broadly cuneate at base, prominently nerved, glabrous above and pale below. Peduncle is $1-2 \mathrm{~cm}$ with 3 or more flowers. Flowers are bright red and occur in axillary cymes. Sepals ovate, to $0.5 \mathrm{~cm}$ long. Corolla is funnel shaped, bright red in color and $3-4 \mathrm{~cm}$ long, tube narrow at base, widening towards tip and lobes spreading. Stamens included, unequal. Ovary is 4locular and fruit is a 4-seeded, leathery, dry ellipsoid berry with yellow-brown color on ripening13,18,19,22.

\section{PHYTOCHEMISTRY OF A. CUNEATA}

Alkaloids such as lysergene, chanoclavine, setoclavine, agroclavine, and isosetoclavine are identified in A. cuneata using 2-D TLC protocol23. Quercetin, kaempferol and/or luteolin-glycosides are found in A. cuneata ${ }^{24}$. Phytochemicals such as indole, isoquinoline, pyrrolidine, tropane alkaloids have been detected in the plant ${ }^{25}$.
Phytochemical groups viz. tannins, steroids, alkaloids, phenolic compounds, flavonoids, glycosides and triterpenoids have been detected in leaves ${ }^{\mathbf{2 6}}$.

\section{ETHNOBOTANICAL USES OF A. CUNEATA}

Argyreia cuneata is used traditionally as a remedy against certain human and veterinary ailments. A. cuneata is used for the treatment of arthritis, diabetes, bone fracture, scabies. The root extract is administered to initiate labor pain, to ease delivery and to expel placenta. As a veterinary medicine, the extract from leaves is given to cattle in order to treat swelling of throat and anorexia15,27. The leaves are used for treatment of diabetes ${ }^{\mathbf{2 8}}$. The leaves of $A$. cuneata are pounded with leaves of Lantana camara and the paste obtained is used to massage painful joints by Jenukurubas in Karnataka. Paste made from leaves is also applied for curing intermittent fever ${ }^{\mathbf{2 9}, 30}$. More information on ethnomedicinal uses of $A$. cuneata is presented in Table 1.

\section{Table 1: Ethnobotanical uses of $A$. cuneata}

\begin{tabular}{|c|c|c|}
\hline Region/area & Uses & Reference \\
\hline Karnataka, India & $\begin{array}{l}\text { The tribal communities of Kodagu district use root mixed with lemon juice } \\
\text { to expel intestinal worms. The milk extract of leaves in water is taken } \\
\text { internally for treating diabetes. }\end{array}$ & Lingaraju et al. ${ }^{5}$ \\
\hline Karnataka, India & $\begin{array}{l}\text { The leaf juice together with coffee seeds and rice are used in } \\
\text { ethnoveterinary practices against retention of fetal membrane in } \\
\text { Mallenahalli village of Chikmagalur taluk. }\end{array}$ & $\begin{array}{l}\text { Raveesha and } \\
\text { Sudhama }\end{array}$ \\
\hline Tamil Nadu, India & $\begin{array}{l}\text { The decoction prepared from leaves is used to manage diabetes by Irula } \\
\text { tribes of Tamil Nadu, India. }\end{array}$ & $\begin{array}{l}\text { Dhivya and } \\
\text { Kalaichelvi32 }\end{array}$ \\
\hline Tamil Nadu, India & $\begin{array}{l}\text { Malayali tribe of Tamil Nadu uses the fibre from the leaves for home } \\
\text { construction purpose }\end{array}$ & Prabakaran et al. ${ }^{33}$ \\
\hline Karnataka, India & $\begin{array}{l}\text { Leaf paste is applied externally to treat skin cuts in Mysore and Coorg } \\
\text { districts. }\end{array}$ & $\begin{array}{l}\text { Kshirsagar and } \\
\text { Singh }^{34}\end{array}$ \\
\hline Karnataka, India & The plant is used in the management of diabetes in Hassan district. & $\begin{array}{l}\text { Kumar and } \\
\text { Shiddamallayya } \\
\text { 35 }\end{array}$ \\
\hline $\begin{array}{l}\text { Southern Eastern } \\
\text { Ghats, India }\end{array}$ & The plant is used by ethnic communities to manage diabetes. & Sivaraj et al. ${ }^{27}$ \\
\hline $\begin{array}{l}\text { Southern western ghats } \\
\text { Coimbatore, India }\end{array}$ & Leaves are used as fodder for goats & $\begin{array}{l}\text { Sarvalingam and } \\
\text { Rajendran } \\
\text { 36 }\end{array}$ \\
\hline
\end{tabular}




\section{PHARMACOLOGICAL ACTIVITIES OF A. CUNEATA}

Studies have shown that $A$. cuneata exhibit some pharmacological activities such as antidiabetic activity, antimicrobial activity, antioxidant activity, analgesic activity, antipyretic activity and wound healing activity. A brief description on pharmacological potential of $A$. cuneata is described below.

\section{Antidiabetic activity}

Ethanol extract of leaves of $A$. cuneata was shown to display significant antidiabetic activity in terms of reduction in the serum glucose level, improving body weight, normalizing the altered lipid profile and increasing the high density lipoprotein and total protein level ${ }^{37}$. The study of Malathi et al. ${ }^{38}$ also revealed the antidiabetic potential of methanolic extract of leaves of $A$. cuneata in male Wister rats induced with diabetes by streptozotocin. Vankudri ${ }^{26}$ evaluated antidiabetic activity of petroleum ether and alcohol extract of leaves by alloxan induced diabetes in rats. Treatment of animals with extracts revealed considerable reduction in blood sugar level. A reduction in the level of blood urea, total triglycerides, cholesterol and an increase in the body weight was observed.

\section{Analgesic activity}

Malathi et al. ${ }^{39}$ evaluated analgesic potential of $A$. cuneata by hot plate method and heat conduction method. The leaf extract showed a significant dose dependent analgesic potential.

\section{Antipyretic activity}

In a study, ethanol-water extract of leaves was shown to display concentration dependent anti-pyretic activity against brewer's yeast induced pyrexia in rats. Extract administration revealed by dose dependent reduction in rectal temperature ${ }^{\mathbf{4 0}}$.

\section{Wound healing activity}

Ethanol-water extract of leaves was also shown to display wound healing activity as studied by excision wound model in Wistar rats. The hydroalcoholic extract and leaf juice showed $91.29 \%$ and $96.07 \%$ wound healing, respectively 40 .

\section{Anthelmintic activity}

Jadhav et al. ${ }^{41}$ evaluated anthelmintic activity of methanol and aqueous extracts of A. cuneata in earthworm model. It was observed that extracts were found to exhibit concentration dependent paralysis and death of earthworms. Methanol extract showed marked anthelmintic potential when compared to aqueous extract.

\section{Antibacterial activity}

Kekuda et al.42 investigated antibacterial potential of leaf, stem and flower extracts of $A$. cuneata by agar well diffusion method. Extracts displayed varied inhibitory activity against gram positive and gram negative bacteria with marked activity being exhibited by leaf extract followed by flower and stem extracts. Among bacteria, Bacillus cereus displayed highest susceptibility to extracts.

\section{Antifungal activity}

The leaf, stem and flower extracts of $A$. cuneata were screened for antifungal activity by poisoned food technique. The extracts were effective in causing suppression of mycelial growth of two seed-borne fungi viz. Bipolaris sp. and Aspergillus niger. Among extracts, marked antifungal activity was shown by leaf extract ${ }^{42}$.
Various extracts, viz. leaf, stem and flower extracts, of $A$. cuneata were effective against seed-borne Penicillium species. Inhibitory activity observed was in the order: leaf extract $>$ flower extract $>$ stem extract ${ }^{43}$.

\section{Antioxidant activity}

Kekuda et al. ${ }^{42}$ determined antioxidant activity of methanol extract of leaf, stem and flower of $A$. cuneata by DPPH scavenging, ABTS scavenging and ferric reducing assays. Extracts displayed scavenging and reducing potential in a dose dependent manner. The antioxidant activity of extracts observed was in the order: leaf extract $>$ flower extract $>$ stem extract.

\section{CONCLUSIONS}

An extensive literature survey on the plant A. cuneata revealed its potential utilization as traditional medicine for treating human and veterinary ailments. Various phytochemicals have been identified in the plant. Pharmacological activities such as wound healing, anthelmintic analgesic, antipyretic, antimicrobial, antioxidant and antidiabetic activity of the plant are investigated. The results obtained from biological activity determinations justify the traditional utilization of the plant and provide an opportunity for future studies concerning recovery of phytochemicals from the plant which may have some therapeutic significance.

\section{ACKNOWLEDGEMENTS}

Authors are thankful to Principal, S.R.N.M.N College of Applied Sciences, and N.E.S, Shivamogga for the immense support given while writing this review.

\section{SOURCES OF FUNDING}

None

\section{CONFLICTS OF INTEREST}

None declared

\section{REFERENCES}

1. Sheng-Ji P. Ethnobotanical approaches of traditional medicine studies: Some experiences from Asia. Pharm Biol 2001; 39(Suppl 1):74-79.

2. Rios JC, Recio MC. Medicinal plants and antimicrobial activity. J Ethnopharmacol 2005; 100(1-2):80-84.

3. Ghorbani A, Naghibi F, Mosaddegh M. Ethnobotany, ethnopharmacology and drug discovery. Iranian J Pharm Sci 2006; 2(2):109-118.

4. Rafieian-Kopaei M. Medicinal plants and the human needs. J HerbMed Pharmacol 2012; 1(1):1-2.

5. Lingaraju DP, Sudarshana MS, Rajashekar N. Ethnopharmacological survey of traditional medicinal plants in tribal areas of Kodagu district, Karnataka, India. J Pharm Res 2013; 6(2):284-297.

6. Hosseinzadeh S, Jafarikukhdan A, Hosseini A, Armand R. The Application of medicinal plants in traditional and modern medicine: A review of Thymus vulgaris. International Journal of Clinical Medicine 2015; 6:635-642.

7. Maroyi A, Cheikhyoussef A. A comparative study of medicinal plants used in rural areas of Namibia and Zimbabwe. Indian J Tradit Know 2015; 14(3):401-406.

8. Eldeen IMS, Effendy MAW, Tengku- Muhammad TS. Ethnobotany: Challenges and Future Perspectives. Research Journal of Medicinal Plants 2016; 10(6-7):382-387. 
9. Zank S, Hanazaki N. The coexistence of traditional medicine and biomedicine: A study with local health experts in two Brazilian regions. PLoS ONE 2017; 12(4):e0174731.

10. Joseph A, Mathew S, Skaria BP, Sheeja EC. Medicinal uses and biological activities of Argyreia speciosa Sweet (Hawaiian Baby Woodrose) - An overview. Indian J Nat Prod Resour $2011 ; 2(3): 286-291$

11. Bhat GK. Flora of South Kanara (Dakshina Kannada and Udupi districts of Karnataka). Mangalore: Akriti Prints; 2014, Pp. 702 .

12. Yang S, Chen P, Staples GW. Argyreia akoensis (Convolvulaceae), a new species from southern Taiwan. Taiwania 2015; 60(3):117-122.

13. Saldanha CJ, Nicolson DH. Flora of Hassan district, Karnataka, India. Amarind Publishing Co Pvt Ltd, New Delhi, India, 1976, Pp 464.

14.

http://florakarnataka.ces.iisc.ac.in/hjcb2/herbsheet.php?id= $1147 \&$ cat $=1$ (retrieved on $5^{\text {th }}$ November 2018)

15. Quattrocchi U. CRC world dictionary of medicinal and poisonous plants. CRC press, Boka Raton, 2012, Pp 376

16. Pullaiah T. Flora of Telangana - The 29th state of India. J Indian Bot Soc 2015; 94(1\&2):1-8.

17. Shiddamallayya N, Rao RV, Doddamani SH, Venkateshwarlu G. A glimpse on forest flora and Indian system of medicine plants of Chitradurga district, Karnataka. International Journal of Herbal Medicine 2016; 4(1):25-33.

18. Manjunatha BK, Krishna V, Pullaiah T. Flora of Davanagere district, Karnataka, India. Regency Publications, New Delhi, India, 2004, Pp 265.

19. Pullaiah T, Naidu CK. Antidiabetic Plants in India and Herbal Based Antidiabetic Research. Regency Publications, New Delhi, 2003, Pp 89-90.

20. Ghate HV, Borowiec L, Rane NS, Ranade SP, Pandit S. Tortoise beetles and their host plants from Pune (Maharashtra State, India) and nearby places (Coleoptera: Chrysomelidae: Cassidinae). Genus. International Journal of Invertebrate Taxonomy 2003; 14(4):519-539.

21. Pimpodkar NV, Surve BS, Bhise SH. Use of Argyreia cuneata flower extract as a natural indicator in acid base titration. Journal of Current Pharma Research 2014; 4(2):1124-1127.

22. Gamble JS. Flora of the Presidency of Madras. Volume II. Bishen Singh Mahendra Pal Singh, Dehra Dun, India, 1993, Pp 909.

23. Chao J, DerMarderosian AH. Identification of ergoline alkaloids in the genus Argyreia and related genera and their chemotaxonomic implications in the convolvulaceae. Phytochemistry 1973; 12:2435-2440.

24. Bever OB. Oral hypoglycemic plants in West Africa. J Ethnopharmacol 1980; 2:119-127.

25. Semwal DK, Bamola A, Rawat U. Chemical constituents of some antidiabetic plants. Universities' Journal of Phyto-chemistry and Ayurvedic Heights 2007; 2:40-48.

26. Vankudri RN. Phytochemical investigations and pharmacological evaluation of Argyreia cuneata (wild). ker leaves for anti-diabetic activity. M.Pharma thesis, Rajiv Gandhi University of Health Sciences, Bangalore, Karnataka, 2010.

27. Sivaraj N, Kamala V, Pandravada SR, Sunil N, Elangovan M, Babu SB, Chakrabarty SK, Varaprasad KS, Krishnamurthy KV. Floristic ecology and phenological observations on the
Medicinal flora of Southern Eastern Ghats, India. Open Access Journal of Medicinal and Aromatic Plants 2014; 5(2):5-22.

28. Kumar S, Saini M, Kumar V, Prakash O, Arya R, Rana M, Kumar D. Traditional medicinal plants curing diabetes: A promise for today and tomorrow. Asian J Tradit Med 2012; 7(4):178-188.

29. Kshirsagar RD, Singh NP. Some less known ethnomedicinal uses from Mysore and Coorg districts, Karnataka, Southern India. Ancient Science of Life 2001; 20:20-25.

30. Kshirsagar R, Saklani A. Ethnomedicinal plants for diabetes, jaundice and rheumatism in karnataka and their comparison with Northeast India. In: Advances in Ethnobotany, Das AP, Pandey AK (Editors), Bishen Singh Mahendra Pal Singh, Dehra Dun, India, 2007, 95-116.

31. Raveesha HR, Sudhama VN. Ethnoveterinary practices in Mallenahalli of Chikmagalur taluk, Karnataka. Journal of Medicinal Plants Studies 2015; 3(1):37-41.

32. Dhivya SM, Kalaichelvi K. Medicinal plants used by Irula tribes of Nellithurai Beat, Karamadai Range, Western Ghats, Tamil Nadu, India: An ethnobotanical survey. Journal of Medicinal Plants Studies 2016; 4(4):270-277.

33. Prabakaran R, Kumar ST, Rao MV. Role of non timber forest products in the livelihood of malayali tribe of Chitteri hills of Southern Eastern Ghats, Tamil Nadu, India. J Appl Pharm Sci 2013; 3(5):56-60.

34. Kshirsagar RD, Singh NP. Some less known ethnomedicinal uses from Mysore and Coorg districts, Karnataka state, India. J Ethnopharmacol 2001; 75:231-238.

35. Kumar PGM, Shiddamallayya N. Survey of wild medicinal plants of Hassan district, Karnataka. Journal of Medicinal Plants Studies 2016; 4(1):91-102.

36. Sarvalingam A, Rajendran A. Climbing plants of the southern western ghats of Coimbatore in India and their economic uses. American-Eurasian J Agric Environ Sci 2015; 15(7):1312-1322.

37. Biradar SM, Rangani AT, Kulkarni VH, Joshi H, Habbu PV, Smita DM. Prevention of onset of hyperglycemia by extracts of Argyriea cuneata on alloxan-induced diabetic rats. J Pharm Res 2010; 3(9):2186-2187.

38. Malathi S, Balasubramaniam V, Kumar JS, Kumar NR, Kaffoor AH. Antidiabetic effect of methanolic leaf extract of Argyreia cuneata Willd. Ex Ker- Awl. (Convolvulaceae). World J Pharm Pharm Sci 2017; 6(8):1650-1663.

39. Malathi S, Balasubramaniam V, Kumar NR, Kumar JS. Evaluation of analgesic activity of methanolic leaf extract of Argyreia cuneata Willd. (Convolvulaceae). Int J Pharm Biol Sci 2017; 7(4):231-234

40. Manda RM, Seru G, Bakshi V. Evaluation of anti-pyretic and wound healing activities of Argyreia cuneata in Wistar Albino rats. Int J Pharm Biol Sci 2016; 6(2):111-113.

41. Jadhav AB, Davande PU, Gaikwad HA, Bhokare PV, Baid KJ. Anthelmentic activity of leaves and stem of Argyreia cuneata. World J Pharm Res 2017; 6(6):866-874.

42. Kekuda PTR, Bharadwaj NA, Sachin MB, Sahana BK, Priyanka GS. In-vitro antimicrobial and antioxidant activity of Argyreia cuneata (Willd.) Ker Gawl. (Convolvulaceae). J Drug Delivery Ther 2018; 8(6):22-27.

43. Sahana BK, Priyanka GS, Kavya SH, Shwetha R, Vinayaka KS Kekuda PTR. 2018. Antifungal activity of some botanical extracts against seed-borne Penicillium species. Journal of Medicinal Plants Studies 6(6):91-94. 